\title{
RESPONSES OF SULFUR AND PHOSPHORUS DOSES ON THE YIELD AND QUALITY OF FENUGREEK (Trigonella foenum-graecum L.)
}

\author{
ÖZYAZICI, G. \\ Department of Field Crops, Faculty of Agriculture, Siirt University, Siirt, Turkey \\ e-mail: gulenozyazici@siirt.edu.tr; phone: +90-533-221-8208 \\ (Received 24 $4^{\text {th }}$ Feb 2020; accepted $9^{\text {th }}$ Jul 2020)
}

\begin{abstract}
This study was conducted to determine the effects of sulfur and phosphorus doses on the yield and quality of fenugreek in Siirt, Turkey, in the 2016-2017 and 2017-2018 growing seasons. Field trials were designed in a factorial complete block design with three replications at the experimental fields of the Agricultural Faculty of Siirt University. In the study, plant height $(\mathrm{cm})$, first pod height $(\mathrm{cm})$, the number of pods (pod plant $\left.{ }^{-1}\right)$, the number of seeds in the pod $\left(\operatorname{seed~pod~}^{-1}\right)$, pod length $(\mathrm{cm})$, thousand-seed weight $(\mathrm{g})$, seed yield $\left(\mathrm{kg} \mathrm{ha}^{-1}\right)$, protein content $(\%)$ and trigonelline content $(\%)$ were determined. All of the growth and yield parameters, except for plant height and pod length, were significantly affected by sulfur fertilization. All the parameters were affected by phosphorus fertilization. The highest seed yield $\left(2224 \mathrm{~kg} \mathrm{ha}^{-1}\right)$ and trigonelline content $(1.26 \%)$ were obtained under $30 \mathrm{~kg} \mathrm{~S} \mathrm{ha}^{-1}$ and $90 \mathrm{~kg} \mathrm{P} \mathrm{ha}^{-1}$ applications.
\end{abstract}

Keywords: Trigonella foenum-graecum, fertilizer, medicinal plants, seed yield, trigonelline

\section{Introduction}

Nowadays, due to the many side effects of synthetic and chemical drugs, trending towards alternative medicine or complementary medicine is gradually increasing. Medicinal and aromatic plants used for this purpose can be found in Turkey among many other countries, mainly by gathering from the natural flora. Therefore, medicinal plants of the desired quantity and quality cannot be obtained. This situation brings up the production of medicinal and aromatic plants with increasing the usage area.

Fenugreek (Trigonella foenum-graecum L.) which is grown for its seeds, fresh shoots, and leaves and is an important multi-purpose plant, one of the oldest known to have medicinal and aromatic properties. It has Mediterranean and Asian origin, and is an annual plant belonging to the Leguminosae family (Baldemir and İlgün, 2015; Bienkowski et al., 2016), containing about 50 species, and 45 of these species are found in the natural flora of Turkey (Davis, 1982; Beyzi et al., 2010). India is the world's largest producer of fenugreek, and it is also grown in South Asia, the Middle East, Far East, China, Iran, Pakistan, Turkey, the Mediterranean region, Europe, North Africa, Australia, Canada, the USA, and Argentina (Basu et al., 2019).

Fenugreek is a plant that has economic value in food, feed, medicine, and cosmetics. Fenugreek seeds are used in traditional medicine in the treatment of diabetes and cancer, as a natural dyestuff in the cosmetics industry, in animal feeding, as a coating material of some products in the food industry, and in making spices (Boeker, 1963; Baytop, 1984; Arslan et al., 1989; Hornok, 1992; Akgül, 1993; Küçük and Gürbüz, 1999; Soylu et al., 2000; Kızıl and Arslan, 2003; Tunçtürk et al., 2011; Abd Elhamid et al., 2016). It is also used as a green manure plant since it is a legume plant, and it has been reported to play a role in improving the physical and chemical properties of the soil (Abdelgani et al., 1999). 
Phosphorus (P), which fulfills many functions related to plant growth, development, and metabolism and is essential for young tissues and cannot be renewed, is the most crucial macronutrient element after nitrogen. It is also called the key to life because it regulates many metabolic activities of plant life. If sufficient $\mathrm{P}$ is given to the plant, it causes rapid growth and increases plant resistance. In the case of $\mathrm{P}$ deficiency, plants stop and slow down the growth of the above-ground organs and accelerate the root growth. P, which also plays an essential role in increasing the yield of legumes by increasing biological activities such as nodulation, nitrogen fixation, nutrient uptake in the soil and in the rhizosphere environment, alleviates adverse effects of drought on physiological parameters in plants (Kacar and Katkat, 2007; Turan and Horuz, 2012; Yadav et al., 2014; Singh and Singh, 2016; Gezgin, 2018).

Generally, the properties of soils in Turkey affect the uptake of soil phosphorus by plants negatively (high $\mathrm{pH}$, high lime content, low organic matter content, high clay content). It is very important to apply appropriate amounts of $\mathrm{P}$ to legume plants or to increase the availability of soil phosphorus, according to the results of soil analysis (Gezgin, 2018). Legumes' benefiting from soil phosphorus also differs according to its species and varieties (Gökmen Y1lmaz et al., 2017).

Elemental sulfur (S) is a natural material and can be applied to increase the availability of plant nutrients and to reduce deficiencies in calcareous and alkaline soils (Manesh et al., 2013). Sulfur has vital importance in the activation of the process of photosynthesis, carbohydrate metabolism, and certain enzyme systems in plants; it can increase plants' seed and oil yields and protein contents. It is considered to be an essential nutrient in the vitamin and amino acids synthesis of legume plants. Sulfur is found in cysteine, cystine, and methionine, among the amino acids, and in the composition of proteins. It is necessary for chlorophyll formation (Lal et al., 2015). It accelerates root growth and nodule formation (Tonguç et al., 2017; Bolat and Kara, 2017). It has been reported that the amount of nitrogen fixed by legumes increases with the treatment of sulfur, and as a result of this, soil fertility improves (Mohamed ElSayed Ali, 2018).

The reduced use of fossil fuels in the world and in Turkey and the widespread use of sulfur-free fertilizers have caused sulfur deficiency to emerge as a factor limiting the yield in plant production. Sulfur affects nitrogen utilization efficiency, and adverse effects of sulfur deficiency are observed on the growth of plants, chlorophyll amount, photosynthesis capacities, yield, and yield parameters (Tonguç et al., 2017). Sulfur positively affects not only the above-ground organs of plants but also the root growth, just like phosphorus. As a matter of fact, in the soybean plant given sulfur, the number and weight of side roots, the number and weight of nodules in which nitrogen fixation occurred were reported to increase significantly (Zhao et al., 2008). In beans, plant weight, the number of branches, the number of pods, the number of grains per plant, thousand-seed weight, harvest index, and yield were indicated to significantly increase in comparison with unfertilized plants (Tonguç et al., 2017).

This study was conducted to determine the effects of sulfur and phosphorus doses on the yield and quality characteristics of fenugreek (T. foenum-graecum L.).

\section{Materials and methods}

The study was carried out between 2016-2018 under the ecological conditions of Siirt province located in the Southeastern Anatolia Region of Turkey, which has a 
semi-arid climate. Siirt is located at $37^{\circ} 58^{\prime} 7.37^{\prime \prime} \mathrm{N}$ and $41^{\circ} 51^{\prime} 3.87^{\prime \prime}$ E coordinates with 894 m altitude (Figure 1, Figure 2).

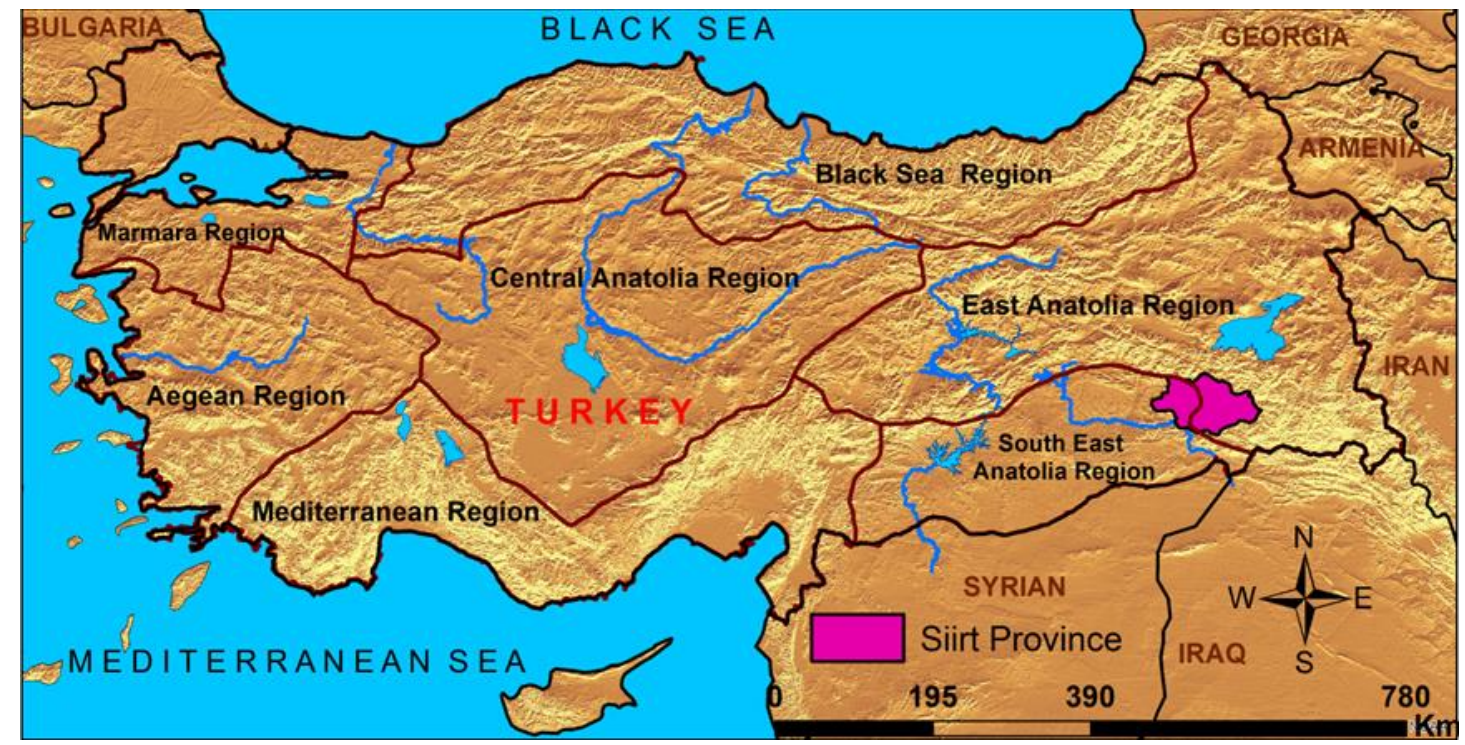

Figure 1. Location of the study area in Turkey
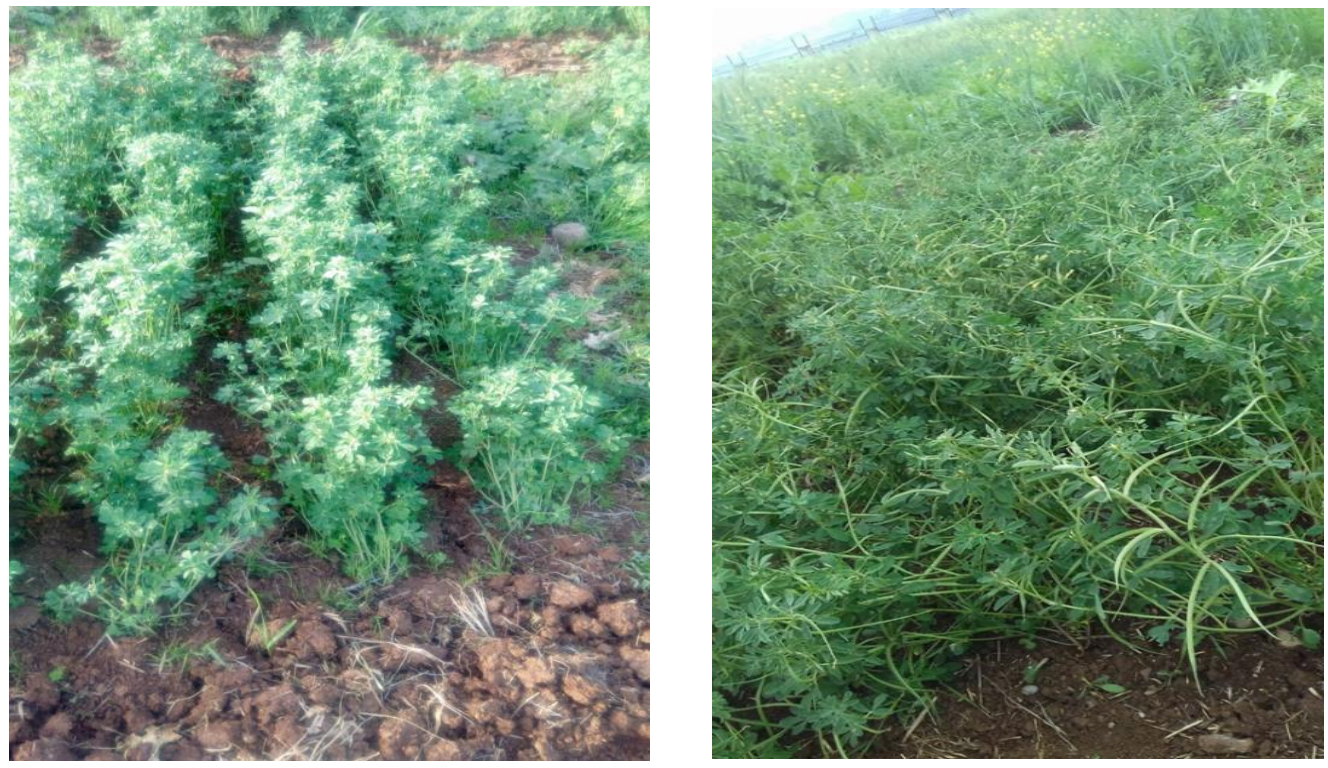

Figure 2. A photo of the research area

In the second year of the study, less precipitation $(522.8 \mathrm{~mm})$ occurred in comparison with the first year $(574.2 \mathrm{~mm})$, while the long-term annual precipitation was $634.1 \mathrm{~mm}$. While the highest precipitation occurred in March and April during the 2016-2017 vegetation period, the highest precipitation was recorded in May during the 2017-2018 vegetation period (Table 1). The mean temperature during the study years and the long-term mean temperature (38 years) were $11.2{ }^{\circ} \mathrm{C}, 13.8^{\circ} \mathrm{C}$, and $11.4^{\circ} \mathrm{C}$, respectively Table 1 (Anonymous, 2018). 
Table 1. Climate characteristics of trial area

\begin{tabular}{c|c|ccccccccc}
\hline \multirow{2}{*}{$\begin{array}{c}\text { Climate } \\
\text { parameters }\end{array}$} & Research & \multicolumn{8}{|c}{ Months } \\
\cline { 3 - 10 } & years & Nov & Dec & Jan & Feb & Mar & Apr & May & June & Mean/Sum \\
\hline $\begin{array}{c}\text { Average } \\
\text { temparature }\end{array}$ & $2016-2017$ & 10.4 & 3.3 & 3.0 & 2.7 & 9.6 & 14.0 & 19.5 & 26.9 & 11.2 \\
$\left({ }^{\circ} \mathrm{C}\right)$ & $2017-2018$ & 11.2 & 8.0 & 5.7 & 8.2 & 13.7 & 16.8 & 19.8 & 27.4 & 13.8 \\
\hline Monthly & Long term & 10.3 & 4.9 & 3.0 & 4.5 & 8.8 & 14.3 & 19.5 & 26.2 & 11.4 \\
precipitation & $2016-2017$ & 55.4 & 116.6 & 46.4 & 29.2 & 119.2 & 132.8 & 74.6 & 0.0 & 574.2 \\
$(\mathrm{~mm})$ & $2017-2018$ & 86.0 & 47.4 & 56.4 & 74.2 & 47.6 & 61.6 & 139.6 & 10.0 & 522.8 \\
& Long term & 85.1 & 91.1 & 82.2 & 96.6 & 108.7 & 96.3 & 64.3 & 9.8 & 634.1 \\
\hline
\end{tabular}

*: 1980-2018

In the study, some physical and chemical analysis results of the soils taken before establishing the field trial were presented in Table 2. In the first year (2016-2017), the trial area soils were loamy textured, and they were clay-loam textured in the second year (2017-2018); both trial area soils were slightly alkaline, salt-free, their lime content was "medium calcareous," the organic matter content was "low," and the available potassium (K) content was "sufficient". The available P content of the soils in the first year was determined to be "very little," and the available P content of the soils in the second year was determined to be "low" (Table 2).

Table 2. Some physical and chemical properties of the study area soils $(0-20 \mathrm{~cm})^{*}$

\begin{tabular}{c|c|c}
\hline \multirow{2}{*}{ Properties } & \multicolumn{2}{|c}{ Value } \\
\cline { 2 - 3 } & $\mathbf{2 0 1 6 - 2 0 1 7}$ & $\mathbf{2 0 1 7 - 2 0 1 8}$ \\
\hline Clay, \% & 47.56 & 34.16 \\
$\mathrm{Silt} \%$ & 12.11 & 26.00 \\
$\mathrm{Sand} \%$ & 40.33 & 39.84 \\
$\mathrm{pH}$ & 7.72 & 7.53 \\
Electrical conductivity (EC), $\mathrm{mS} \mathrm{cm}^{-1}$ & 0.363 & 0.150 \\
Lime $\left(\mathrm{CaCO}_{3}\right) \%$ & 12.0 & 8.2 \\
Organic matter, \% & 1.31 & 1.78 \\
Available phosphorus, $\mathrm{kg} \mathrm{P}_{2} \mathrm{O}_{5} \mathrm{ha}^{-1}$ & 24 & 49 \\
Available potassium, $\mathrm{kg} \mathrm{K}_{2} \mathrm{O} \mathrm{ha}^{-1}$ & 1430 & 1250 \\
\hline
\end{tabular}

*: Analyses were carried out in Siirt University, Science and Technology Application and Research Center Laboratory

As the plant material in the study, fenugreek ( $T$. foenum-graecum L.) seeds, belonging to the "Konya population" and seeded locally in the Central Anatolia Region of Turkey, were used.

In this study, the field trial was established as three replications in randomized blocks according to the factorial trial design. In the study, 4 different sulfur doses $\left(\mathrm{S}_{0}=0\right.$, $\mathrm{S}_{10}=10, \mathrm{~S}_{20}=20$, and $\left.\mathrm{S}_{30}=30 \mathrm{~kg} \mathrm{~S} \mathrm{ha}^{-1}\right)$ and 4 different phosphorus doses $\left(\mathrm{P}_{0}=0\right.$, $\mathrm{P}_{30}=30, \mathrm{P}_{60}=60$, and $\mathrm{P}_{90}=90 \mathrm{~kg} \mathrm{P}_{2} \mathrm{O}_{5} \mathrm{ha}^{-1}$ ) constituted the subject of the study. Elemental sulfur was used as the source of sulfur fertilizer, and triple superphosphate (43-44\% $\left.\mathrm{P}_{2} \mathrm{O}_{5}\right)$ was used as the source of phosphorus fertilizer. According to the 
research subjects, both fertilizer forms were mixed by applying them to the soil before seeding.

The seeding process was performed manually on 14 November 2016 in the first year and on 17 November 2017 in the second year on the grooves opened with the help of a marker. In the study, row distance was $30 \mathrm{~cm}$ and parcel distance was $100 \mathrm{~cm}$. Each parcel constituted from four rows, while length and width of the parcels were 3 meter by 1.2 meter each with a total area of $3.6 \mathrm{~m}^{2}$ per parcel. Sowing norm was $30 \mathrm{~kg} \mathrm{ha}^{-1}$, and sowing was done manually in rows opened with the help of a marker. Weed control was performed mechanically by hand several times in both years. At the harvest, two border rows and $50 \mathrm{~cm}$ from each side were excluded to eliminate border effects.

Plant height, first pod height, pod length, the number of pods per plant, and the number of seeds per pod were determined in 10 plants randomly selected in each parcel before harvest. The harvest was carried in the entire plot area, excluding borders in the first week of July in both years. The harvested plants were dried in the shade for 3-4 days, and seed yields were calculated per hectare. Crude protein determination in seeds was performed by the Kjeldahl nitrogen determination method, and trigonelline analysis was performed by the HPLC method. In trigonelline analysis was used Agilent TC-C18 (ODS $25 \mathrm{~cm} * 4.6 \mathrm{~mm}$ ) column. Column temperature was maintained at $27{ }^{\circ} \mathrm{C}$ and the flow rate of the mobile phase was kept at $1 \mathrm{ml}$ per min. The changes in absorbance at wavelength $210 \mathrm{~nm}$ were recorded with UV detector. The peak area was calibrated to trigonellin content with a standard.

The data were analyzed by JMP statistical software. A homogeneity test was applied to the data obtained from the study. According to the results of the homogeneity test, they were subjected to combined variance analysis (ANOVA) according to the factorial trial design in randomized blocks. According to the F-test results, differences between the groups were determined by the LSD multiple comparison test. In the study, the correlation coefficients of the pairwise relationships between the examined properties were calculated (Yurtsever, 1984; Düzgüneş et al., 1987).

\section{Results and discussion}

\section{Plant height}

In the study, the effect of $S$ doses on the plant height of fenugreek was statistically insignificant, and according to $S$ doses, plant height varied between $62.4-65.2 \mathrm{~cm}$ as the mean of $\mathrm{P}$ doses and years. The effect of phosphorus doses on plant height was determined to be statistically significant at the $\mathrm{p}<0.01$ level. This difference occurred between the $\mathrm{P}_{0}$ and $\mathrm{P}_{30}$ doses of phosphorus and its $\mathrm{P}_{60}$ and $\mathrm{P}_{90}$ doses. In this study, in which plant height increased according to $\mathrm{P}$ doses, the highest plant height was determined in $\mathrm{P}_{60}(65.2 \mathrm{~cm})$ and $\mathrm{P}_{90}(66.3 \mathrm{~cm}) \mathrm{P}$ doses. When the interaction of SxP was examined, the highest plant height was determined in the $\mathrm{S}_{0} \mathrm{P}_{90}$ application as $70.1 \mathrm{~cm}$, but no statistically significant difference was found between it and $\mathrm{S}_{0} \mathrm{P}_{60}, \mathrm{~S}_{10} \mathrm{P}_{60}, \mathrm{~S}_{10} \mathrm{P}_{90}$, $\mathrm{S}_{30} \mathrm{P}_{0}$, and $\mathrm{S}_{30} \mathrm{P}_{90}$ applications. The lowest plant height was measured in unfertilized parcels (control). SxP interaction was determined to be statistically significant $(\mathrm{p}<0.01)$ (Table 3). When the studies on this subject were reviewed, increasing $\mathrm{P}$ applications were reported to increase plant height, similarly to the results of our study (Halesh et al., 2000; Khiriya et al., 2001; Nehara et al., 2006; Meena et al., 2012; Mehta et al., 2012; Verma et al., 2014; Srivastava et al., 2015; Ahmad, 2017; Basu et al., 2019). 
Table 3. Means of yield components at different sulfur and phosphorus doses in fenugreek

\begin{tabular}{|c|c|c|c|c|c|c|c|c|c|c|}
\hline \multirow{2}{*}{$\mathrm{S}$ doses } & \multirow{2}{*}{$\begin{array}{c}P \\
\text { doses }\end{array}$} & \multicolumn{3}{|c|}{ Plant height (cm) } & \multicolumn{3}{|c|}{ First pod height (cm) } & \multicolumn{3}{|c|}{ Pod length $(\mathrm{cm})$} \\
\hline & & 2017 & 2018 & Mean ${ }^{1}$ & 2017 & 2018 & Mean ${ }^{1}$ & 2017 & 2018 & Mean $^{1}$ \\
\hline \multirow{4}{*}{$\mathrm{S}_{0}$} & $\mathrm{P}_{0}$ & 59.8 & 57.8 & $58.8 \mathrm{e}$ & 36.4 & 46.2 & 41.3 & 14.4 & 13.3 & 13.8 \\
\hline & $\mathrm{P}_{30}$ & 63.8 & 61.4 & 62.6 cde & 44.5 & 50.1 & 47.3 & 14.5 & 14.6 & 14.6 \\
\hline & $\mathrm{P}_{60}$ & 69.9 & 68.8 & $69.4 \mathrm{ab}$ & 43.5 & 48.9 & 46.2 & 14.8 & 15.3 & 15.0 \\
\hline & $\mathrm{P}_{90}$ & 69.0 & 71.1 & $70.1 \mathrm{a}$ & 42.3 & 52.7 & 47.5 & 15.4 & 16.4 & 15.9 \\
\hline \multicolumn{2}{|c|}{$\mathrm{S}_{0}$ Mean } & 65.6 & 64.8 & 65.2 & 41.7 & 49.5 & $45.6 \mathrm{~A}$ & 14.8 & 14.9 & 14.8 \\
\hline \multirow{4}{*}{$\mathrm{S}_{10}$} & $\mathrm{P}_{0}$ & 60.7 & 56.9 & $58.8 \mathrm{e}$ & 41.3 & 38.2 & 39.8 & 14.1 & 14.5 & 14.3 \\
\hline & $\mathrm{P}_{30}$ & 60.8 & 62.4 & $61.6 \mathrm{de}$ & 40.3 & 42.6 & 41.4 & 14.7 & 15.4 & 15.1 \\
\hline & $\mathrm{P}_{60}$ & 65.1 & 66.5 & $65.8 \mathrm{a}-\mathrm{d}$ & 43.1 & 42.7 & 42.9 & 15.2 & 15.7 & 15.4 \\
\hline & $\mathrm{P}_{90}$ & 66.3 & 68.53 & $67.4 \mathrm{abc}$ & 40.4 & 44.7 & 42.5 & 17.7 & 16.3 & 17.0 \\
\hline \multicolumn{2}{|c|}{$\mathrm{S}_{10}$ Mean } & 63.2 & 63.6 & 63.4 & 41.3 & 42.1 & $41.7 \mathrm{~B}$ & 15.5 & 15.5 & 15.5 \\
\hline \multirow{4}{*}{$\mathrm{S}_{20}$} & $\mathrm{P}_{0}$ & 61.7 & 64.5 & $63.1 \mathrm{cde}$ & 39.9 & 36.1 & 38.1 & 14.2 & 14.2 & 14.2 \\
\hline & $\mathrm{P}_{30}$ & 62.6 & 60.1 & $61.4 \mathrm{de}$ & 39.1 & 40.0 & 39.6 & 15.9 & 15.8 & 15.8 \\
\hline & $\mathrm{P}_{60}$ & 61.7 & 65.7 & 63.7 cde & 43.1 & 43.2 & 43.1 & 15.2 & 15.2 & 15.2 \\
\hline & $\mathrm{P}_{90}$ & 62.6 & 60.1 & $61.4 \mathrm{de}$ & 40.9 & 42.4 & 41.7 & 16.2 & 16.3 & 16.3 \\
\hline \multicolumn{2}{|c|}{$\mathrm{S}_{20}$ Mean } & 62.2 & 62.6 & 62.4 & 40.7 & 40.4 & $40.6 \mathrm{~B}$ & 15.4 & 15.4 & 15.4 \\
\hline \multirow{4}{*}{$\mathrm{S}_{30}$} & $\mathrm{P}_{0}$ & 64.4 & 67.1 & $65.8 \mathrm{a}-\mathrm{d}$ & 35.2 & 35.5 & 35.4 & 14.2 & 14.5 & 14.4 \\
\hline & $\mathrm{P}_{30}$ & 64.1 & 64.3 & $64.2 \mathrm{~b}-\mathrm{d}$ & 43.4 & 40.3 & 41.8 & 15.3 & 15.5 & 15.4 \\
\hline & $\mathrm{P}_{60}$ & 61.3 & 62.5 & $61.9 \mathrm{de}$ & 46.3 & 48.3 & 47.3 & 15.9 & 16.1 & 16.0 \\
\hline & $\mathrm{P}_{90}$ & 66.4 & 66.1 & $66.3 \mathrm{a}-\mathrm{d}$ & 41.8 & 44.6 & 43.2 & 15.2 & 15.6 & 15.4 \\
\hline \multicolumn{2}{|c|}{$\mathrm{S}_{30}$ Mean } & 64.1 & 65.0 & 64.5 & 41.7 & 42.2 & $41.9 \mathrm{~B}$ & 15.2 & 15.4 & 15.3 \\
\hline \multicolumn{11}{|c|}{ Phosphorus mean } \\
\hline \multicolumn{2}{|c|}{$\mathrm{P}_{0}$} & 61.7 & 61.6 & $61.6 \mathrm{~b}$ & 38.2 & 39.0 & $38.6 \mathrm{~b}$ & 14.3 & 14.2 & $14.2 \mathrm{c}$ \\
\hline \multicolumn{2}{|c|}{$\mathrm{P}_{30}$} & 62.8 & 62.1 & $62.5 \mathrm{~b}$ & 41.8 & 43.3 & $42.6 \mathrm{a}$ & 15.1 & 15.3 & $15.2 \mathrm{~b}$ \\
\hline \multicolumn{2}{|c|}{$\mathrm{P}_{60}$} & 64.5 & 65.9 & $65.2 \mathrm{a}$ & 43.9 & 45.8 & $44.9 \mathrm{a}$ & 15.3 & 15.6 & $15.4 \mathrm{~b}$ \\
\hline \multicolumn{2}{|c|}{$\mathrm{P}_{90}$} & 66.1 & 66.5 & $66.3 \mathrm{a}$ & 41.3 & 46.1 & $43.7 \mathrm{a}$ & 16.1 & 16.2 & $16.1 \mathrm{a}$ \\
\hline \multicolumn{2}{|c|}{ Means } & 63.8 & 64.0 & & 41.3 & 43.5 & & 15.2 & 15.3 & \\
\hline \multicolumn{2}{|c|}{$\mathrm{CV}(\%)$} & \multicolumn{3}{|c|}{7.2} & \multicolumn{3}{|c|}{10.8} & \multicolumn{3}{|c|}{6.5} \\
\hline \multicolumn{2}{|c|}{ Year $(Y)$} & \multicolumn{3}{|c|}{ ns } & \multicolumn{3}{|c|}{$*$} & \multicolumn{3}{|c|}{$\mathrm{ns}$} \\
\hline Sulfu & $(S)$ & & ns & & & $* *$ & & & ns & \\
\hline Phospho & rus $(\mathrm{P})$ & & $* *$ & & & $* *$ & & & $* *$ & \\
\hline $\mathrm{Sx}$ & & & $* *$ & & & ns & & & ns & \\
\hline $\mathrm{SxP}$ & & & $\mathrm{ns}$ & & & $\mathrm{ns}$ & & & ns & \\
\hline
\end{tabular}

$\mathrm{S}_{0}=$ Control, $\mathrm{S}_{10}=10 \mathrm{~kg} \mathrm{ha}^{-1}$ sulfur, $\mathrm{S}_{20}=20 \mathrm{~kg} \mathrm{ha}^{-1}$ sulfur, $\mathrm{S}_{3}=30 \mathrm{~kg} \mathrm{ha}^{-1}$ sulfur, $\mathrm{P}_{0}=$ Control, $\mathrm{P}_{30}=30 \mathrm{~kg}$ ha $^{-1}$ phosphorus, $\mathrm{P}_{60}=60 \mathrm{~kg} \mathrm{ha}^{-1}$ phosphorus, $\mathrm{P}_{90}=90 \mathrm{~kg} \mathrm{ha}^{-1}$ phosphorus, ${ }^{I}$ : The difference between the means indicated by the same letter in the same column and group is not significant, CV: Coefficient of variation, ns: Not significant, *: $\mathrm{p}<0.05, * *$ : $\mathrm{p}<0.01$

\section{First pod height}

In the fenugreek plant, $\mathrm{S}$ and $\mathrm{P}$ doses had a statistically significant effect on the first pod height at the $\mathrm{p}<0.01$ level. The highest first pod height was measured in plants in parcels not treated with $S$, and no statistically significant difference was found between the other $\mathrm{S}$ doses. In other words, increased $\mathrm{S}$ doses did not affect the first pod height (Table 3). Tunçtürk et al. (2011) reported that the highest first pod height was obtained in the dose of $40 \mathrm{~kg} \mathrm{~S} \mathrm{ha}^{-1}$ and that contrary to the results of our study, the first pod height increased with increasing $\mathrm{S}$ doses. It is thought that seeding time and genotype differences may be effective in this difference in the literature. As a matter of fact, Babagil (2010) stated that the first pod height is a property that is significantly affected by genotype and environmental factors. When the results of phosphorus doses were examined, as the mean of years and $\mathrm{S}$ doses, the lowest first pod height $(38.6 \mathrm{~cm})$ was 
measured in parcels not treated with phosphorus fertilizer, while the $\mathrm{P}_{30}, \mathrm{P}_{60}$, and $\mathrm{P}_{90}$ doses of phosphorus were statistically in the same group and yielded the highest values (Table 3). In the studies conducted on fenugreek, the highest first pod height was determined in $40 \mathrm{~kg} \mathrm{P} \mathrm{ha}^{-1}$ by Khiriya and Singh (2003) and in $30 \mathrm{~kg} \mathrm{P} \mathrm{ha}^{-1}$ doses by Tunçtürk (2011), Nehara et al. (2006) reported that increased phosphorus doses increased yield properties.

\section{Pod length}

While the effects of $\mathrm{S}$ doses on pod length were statistically insignificant in the fenugreek plant, the effects of $\mathrm{P}$ doses were significant at the $\mathrm{p}<0.01$ level. The pod length varied between 14.8-15.5 $\mathrm{cm}$ according to sulfur doses. The pod length was observed to increase in parallel with the increasing $\mathrm{P}$ doses. The highest pod length was measured to be $16.1 \mathrm{~cm}$ at $\mathrm{P}_{90}$ dose, and the lowest value was measured in the control parcel $(14.2 \mathrm{~cm})$ (Table 3). Similarly to our results, Khiriya et al. (2001), Khiriya and Singh (2003), Bhunia et al. (2006), and Meena et al. (2012) reported that increased P doses increased the pod length.

\section{Number of pods}

The statistical analysis results demonstrated that $\mathrm{S}$ and $\mathrm{P}$ doses and $\mathrm{SxP}$ interaction had significant effects on the number of pods per plant at the $p<0.01$ level. In the study, the number of pods was determined to increase in the fenugreek plant depending on the increase in $\mathrm{S}$ and $\mathrm{P}$ doses. In both fertilizer applications, the highest values were determined at the highest fertilizer doses (Table 4). In the studies conducted by Kumar (2011) on pea and by Nawange et al. (2011) on chickpeas, it was reported that increasing phosphorus and sulfur applications increased the number of pods.

The number of pods per plant was reported to vary between $7.7-8.5$ by Tunçtürk (2011), between 30.6-33.0 by Meena et al. (2012), between 46.73-50.72 by Lal et al. (2015), between 6.4-8.6 by Srivastava et al. (2015), and between 11.6-23.1 by Mitoo et al. (2018). The reason for the number of pods per plant obtained in this study to be higher than these values in the literature may be differences in genotype, soil, climate, and cultural practices.

When the SxP interaction was examined, the highest number of pods was obtained from $\mathrm{S}_{30} \mathrm{P}_{60}$ and $\mathrm{S}_{30} \mathrm{P}_{90}$ applications, while the lowest number of pods was obtained from the $\mathrm{S}_{0} \mathrm{P}_{0}$ application (Table 4).

\section{Number of seeds per pod}

When sulfur applications were examined, it was observed that the number of seeds per pod increased up to $S_{20}$ dose (15.59 seeds) depending on the increase in $\mathrm{S}$ doses, and after this dose, it was observed that it decreased statistically significantly. This difference between sulfur doses was statistically significant at the $\mathrm{p}<0.01$ level. In terms of phosphorus doses, the number of seeds per pod increased with increasing $\mathrm{P}$ doses. Although the highest value was obtained to be 15.85 seeds at $\mathrm{P}_{90}$ dose, the difference between $\mathrm{P}_{90}$ and $\mathrm{P}_{60}$ doses (15.62 seeds) was statistically insignificant. This difference between phosphorus doses was determined to be statistically significant at the $\mathrm{p}<0.01$ level. According to the sulfur x phosphorus interaction, the lowest number of seeds per pod was in $\mathrm{S}_{0} \mathrm{P}_{0}$ interaction (12.40), and the highest values were determined in $\mathrm{S}_{20} \mathrm{P}_{90}$, $\mathrm{S}_{20} \mathrm{P}_{30}, \mathrm{~S}_{20} \mathrm{P}_{60}, \mathrm{~S}_{30} \mathrm{P}_{60}, \mathrm{~S}_{30} \mathrm{P}_{90}, \mathrm{~S}_{0} \mathrm{P}_{90}, \mathrm{~S}_{10} \mathrm{P}_{90}, \mathrm{~S}_{10} \mathrm{P}_{60}$, and $\mathrm{S}_{0} \mathrm{P}_{60}$ interactions. SxP 
interaction was determined to be very important in terms of the number of seeds per pod $(\mathrm{p}<0.01)$ (Table 4). Srivastava et al. (2015) reported that the number of seeds per pod varied between 13.20-16.60 and that the application of phosphorus increased the number of seeds per pod in the fenugreek plant. Mitoo et al. (2018) stated that the number of seeds per pod varied between 11.67-15.07 and increased with increasing phosphorus and sulfur applications.

Table 4. Means of yield components at different sulfur and phosphorus doses in fenugreek

\begin{tabular}{|c|c|c|c|c|c|c|c|c|c|c|}
\hline \multirow{2}{*}{$\begin{array}{c}\mathbf{S} \\
\text { doses }\end{array}$} & \multirow{2}{*}{$\begin{array}{c}\mathbf{P} \\
\text { doses }\end{array}$} & \multicolumn{3}{|c|}{$\begin{array}{l}\text { Number of pods } \\
\text { (pods/plant) }\end{array}$} & \multicolumn{3}{|c|}{$\begin{array}{c}\text { Number of seeds in pod } \\
\text { (seeds/pod) }\end{array}$} & \multicolumn{3}{|c|}{$\begin{array}{c}\text { Thousand-seed weight } \\
\text { (g) }\end{array}$} \\
\hline & & 2017 & 2018 & Mean ${ }^{I}$ & 2017 & 2018 & Mean $^{I}$ & 2017 & 2018 & Mean ${ }^{l}$ \\
\hline \multirow{4}{*}{$\mathrm{S}_{0}$} & $\mathrm{P}_{0}$ & 37.33 & 36.30 & $36.82 \mathrm{~g}$ & 12.89 & 11.90 & $12.40 \mathrm{~d}$ & 12.24 & 13.10 & 12.67 \\
\hline & $\mathrm{P}_{30}$ & 45.70 & 42.57 & $44.13 \mathrm{c}-\mathrm{f}$ & 14.57 & 15.07 & $14.82 \mathrm{bc}$ & 13.23 & 13.20 & 13.21 \\
\hline & $\mathrm{P}_{60}$ & 43.70 & 45.67 & $44.68 \mathrm{cde}$ & 15.46 & 15.63 & $15.55 \mathrm{ab}$ & 13.07 & 13.42 & 13.25 \\
\hline & $\mathrm{P}_{90}$ & 45.60 & 49.30 & $47.45 \mathrm{bc}$ & 15.76 & 16.13 & $15.95 \mathrm{a}$ & 13.52 & 13.30 & 13.41 \\
\hline \multicolumn{2}{|c|}{$\mathrm{S}_{0}$ Mean } & 43.08 & 43.68 & $43.27 \mathrm{~B}$ & 14.67 & 14.68 & $14.68 \mathrm{C}$ & 13.02 & 13.25 & $13.14 \mathrm{~B}$ \\
\hline \multirow{4}{*}{$S_{10}$} & $\mathrm{P}_{0}$ & 39.33 & 39.73 & $39.53 \mathrm{fg}$ & 14.07 & 14.87 & $14.47 \mathrm{c}$ & 12.58 & 13.54 & 13.06 \\
\hline & $\mathrm{P}_{30}$ & 39.93 & 43.13 & $41.53 \mathrm{~d}-\mathrm{g}$ & 14.73 & 14.77 & $14.75 \mathrm{c}$ & 13.73 & 13.89 & 13.81 \\
\hline & $\mathrm{P}_{60}$ & 45.57 & 45.73 & $45.65 \mathrm{~cd}$ & 15.40 & 15.73 & $15.57 \mathrm{ab}$ & 14.27 & 13.62 & 13.95 \\
\hline & $\mathrm{P}_{90}$ & 44.90 & 48.30 & $46.60 \mathrm{bcd}$ & 15.70 & 15.73 & $15.72 \mathrm{a}$ & 13.42 & 14.12 & 13.77 \\
\hline \multicolumn{2}{|c|}{$\mathrm{S}_{10}$ Mean } & 42.43 & 43.97 & $43.33 \mathrm{~B}$ & 14.98 & 15.28 & $15.13 \mathrm{~B}$ & 13.50 & 13.79 & $13.65 \mathrm{AB}$ \\
\hline \multirow{4}{*}{$\mathrm{S}_{20}$} & $\mathrm{P}_{0}$ & 39.70 & 38.47 & $39.08 \mathrm{fg}$ & 14.63 & 14.60 & $14.62 \mathrm{c}$ & 12.64 & 13.21 & 12.93 \\
\hline & $\mathrm{P}_{30}$ & 43.57 & 45.00 & $44.28 \mathrm{cde}$ & 16.17 & 15.87 & $16.02 \mathrm{a}$ & 13.38 & 13.22 & 13.30 \\
\hline & $\mathrm{P}_{60}$ & 48.27 & 46.90 & $47.58 \mathrm{bc}$ & 15.63 & 15.63 & $15.63 \mathrm{a}$ & 13.93 & 13.72 & 13.82 \\
\hline & $\mathrm{P}_{90}$ & 51.90 & 50.03 & $50.97 \mathrm{~b}$ & 16.00 & 16.20 & $16.10 \mathrm{a}$ & 14.60 & 15.91 & 15.26 \\
\hline \multicolumn{2}{|c|}{$S_{20}$ Mean } & 45.86 & 45.10 & $45.48 \mathrm{~B}$ & 15.61 & 15.58 & $15.59 \mathrm{~A}$ & 13.64 & 14.02 & $13.83 \mathrm{~A}$ \\
\hline \multirow{4}{*}{$\mathrm{S}_{30}$} & $\mathrm{P}_{0}$ & 37.93 & 38.93 & $38.43 \mathrm{~g}$ & 14.23 & 14.57 & $14.40 \mathrm{c}$ & 12.67 & 13.18 & 12.93 \\
\hline & $\mathrm{P}_{30}$ & 39.13 & 41.93 & $40.53 \mathrm{efg}$ & 14.83 & 14.80 & $14.82 \mathrm{bc}$ & 12.88 & 13.32 & 13.10 \\
\hline & $\mathrm{P}_{60}$ & 56.33 & 63.20 & $59.77 \mathrm{a}$ & 15.70 & 15.73 & $15.72 \mathrm{a}$ & 14.03 & 14.00 & 14.02 \\
\hline & $\mathrm{P}_{90}$ & 56.77 & 55.97 & $56.37 \mathrm{a}$ & 15.63 & 15.67 & $15.65 \mathrm{a}$ & 15.24 & 15.47 & 15.36 \\
\hline \multicolumn{2}{|c|}{$S_{30}$ Mean } & 47.54 & 50.01 & $48.78 \mathrm{~A}$ & 15.10 & 15.19 & $15.15 \mathrm{~B}$ & 13.70 & 13.99 & $13.84 \mathrm{~A}$ \\
\hline \multicolumn{11}{|c|}{ Phosphorus mean } \\
\hline & 0 & 38.58 & 38.61 & $38.59 \mathrm{c}$ & 13.95 & 13.98 & $13.97 \mathrm{c}$ & 12.54 & 13.31 & $12.90 \mathrm{c}$ \\
\hline & 30 & 42.08 & 43.16 & $42.62 \mathrm{~b}$ & 15.08 & 15.12 & $15.10 \mathrm{~b}$ & 13.83 & 14.20 & $13.36 \mathrm{bc}$ \\
\hline & 60 & 48.47 & 50.38 & $49.42 \mathrm{a}$ & 15.55 & 15.68 & $15.62 \mathrm{a}$ & 13.26 & 13.41 & $13.76 \mathrm{~b}$ \\
\hline & 0 & 49.80 & 50.90 & $50.34 \mathrm{a}$ & 15.78 & 15.93 & $15.85 \mathrm{a}$ & 13.69 & 14.70 & $14.45 \mathrm{a}$ \\
\hline & ans & 44.73 & 45.76 & & 15.09 & 15.18 & & 13.47 & 13.76 & \\
\hline & (\%) & & 8.9 & & & 4.6 & & & 6.6 & \\
\hline Yea & $(\mathrm{Y})$ & & $\mathrm{ns}$ & & & $\mathrm{ns}$ & & & $\mathrm{ns}$ & \\
\hline & $r(S)$ & & ** & & & ** & & & $*$ & \\
\hline Phospl & orus (P) & & ** & & & ** & & & ** & \\
\hline & & & ** & & & ** & & & ns & \\
\hline & $\mathrm{xY}$ & & $\mathrm{ns}$ & & & $\mathrm{ns}$ & & & ns & \\
\hline
\end{tabular}

$\mathrm{S}_{0}=$ Control, $\mathrm{S}_{10}=10 \mathrm{~kg} \mathrm{ha}^{-1}$ sulfur, $\mathrm{S}_{20}=20 \mathrm{~kg} \mathrm{ha}^{-1}$ sulfur, $\mathrm{S}_{30}=30 \mathrm{~kg} \mathrm{ha}^{-1}$ sulfur, $\mathrm{P}_{0}=$ Control, $\mathrm{P}_{30}=30$ $\mathrm{kg} \mathrm{ha}^{-1}$ phosphorus, $\mathrm{P}_{60}=60 \mathrm{~kg} \mathrm{ha}^{-1}$ phosphorus, $\mathrm{P}_{90}=90 \mathrm{~kg} \mathrm{ha}^{-1}$ phosphorus, ${ }^{l}$ : The difference between the means indicated by the same letter in the same column and group is not significant, CV: Coefficient of variation, ns: Not significant, *: $\mathrm{p}<0.05, * *$ : $<<0.01$

\section{Thousand-seed weight}

The results of the statistical analysis showed that $S$ doses had a significant effect on the thousand-seed weight at the $\mathrm{p}<0.05$ level and $\mathrm{P}$ doses at the $\mathrm{p}<0.01$ level. When Table 4 was examined, the highest thousand-seed weight among $\mathrm{S}$ doses was 
determined at $\mathrm{S}_{20}(13.83 \mathrm{~g})$ and $\mathrm{S}_{30}(13.84 \mathrm{~g})$ doses. However, no statistically significant difference was determined between them and $S_{10}(13.65 \mathrm{~g}) \mathrm{S}$ dose (Table 4). Ramkishor and Kumawat (2015) stated that different doses of S applied to the fenugreek plant had significant effects on the thousand-seed weight, and that the application of 40 and $60 \mathrm{~kg}$ $\mathrm{S}$ per hectare increased the thousand-seed weight compared to control subjects. Srivastava et al. (2015) obtained the highest thousand-seed weight to be 13.75 and $13.76 \mathrm{~g}$ at the 40 and $80 \mathrm{~kg} \mathrm{ha}^{-1} \mathrm{P}$ doses, respectively. Tunçtürk et al. (2011) stated that the thousand-seed weight was significantly affected by $\mathrm{S}$ application in the first year and that the highest thousand-seed weight was obtained to be $18.8 \mathrm{~g}$ at dose of $40 \mathrm{~kg} \mathrm{ha}^{-1}$. The increased P doses increased the thousand-seed weight in the fenugreek plant. While the lowest thousand-seed weight was determined at $\mathrm{P}_{0}$ dose $(12.90 \mathrm{~g})$, the highest thousand-seed weight was determined at $\mathrm{P}_{90}$ dose (14.45 g) (Table 4). Tunçtürk (2011) reported that $\mathrm{P}$ doses increased the thousand-seed weight, and the highest thousand-seed weight was obtained from 60 and $90 \mathrm{~kg} \mathrm{ha}^{-1} \mathrm{P}(17.8 \mathrm{~g}$ and $18.0 \mathrm{~g})$ applications. The highest thousand-seed weight was determined by Sammuria and Yadav (2008) from 40 and $60 \mathrm{~kg} \mathrm{ha}^{-1} \mathrm{P}$ application (11.62 $\mathrm{g}$ and $11.74 \mathrm{~g}$, respectively), and by Mitoo et al. (2018) to be $9.98 \mathrm{~g}$ from $40 \mathrm{~kg} \mathrm{ha}^{-1} \mathrm{P}$ application, which was the highest dose.

\section{Seed yield}

The variance analysis results showed that $\mathrm{S}$ and $\mathrm{P}$ doses and $\mathrm{SxP}$ interaction had significant effects on seed yield at the $\mathrm{p}<0.01$ level (Table 5). When Table 5 was examined, it was determined that the highest seed yield was obtained to be $2224 \mathrm{~kg} \mathrm{ha}^{-1}$ from the $\mathrm{S}_{30} \mathrm{P}_{90}$ application, and the lowest seed yield was obtained to be $1038 \mathrm{~kg} \mathrm{ha}^{-1}$ from the $\mathrm{S}_{0} \mathrm{P}_{0}$ application. As $\mathrm{P}$ and $\mathrm{S}$ doses increased, seed yield was determined to increase in fenugreek. In both fertilizer applications, the highest seed yields were determined at the highest fertilizer doses. As the mean of years and P doses, the highest fenugreek seed yield with the sulfur application was obtained to be $1822 \mathrm{~kg} / \mathrm{ha}\left(\mathrm{S}_{30}\right)$, and as the mean of years and $\mathrm{S}$ doses, the highest fenugreek seed yield in phosphorus fertilizer applications was obtained to be $1810 \mathrm{~kg} \mathrm{ha}^{-1}\left(\mathrm{P}_{90}\right)$ (Table 5). Many researchers stated that the phosphorus element is necessary for energy transfer in plants and that the yield, and above ground and root development of the plant are adversely affected in $\mathrm{P}$ deficiency or excess (Kacar and Katkat, 2007; Singh and Singh, 2016). Tunçtürk et al. (2011), Lal et al. (2015), Ramkishor and Kumawat (2015), Singh Manohar et al. (2017), and Verma et al. (2017) reported that increasing sulfur doses increase seed yield, and Halesh et al. (2000), Tunçtürk (2011), and Meena et al. (2012) reported that increasing phosphorus doses increase seed yield in the fenugreek plant.

\section{Protein content}

In the study, the effects of $\mathrm{S}$ and $\mathrm{P}$ doses on the protein content of fenugreek seed were found to be statistically significant $(\mathrm{p}<0.01)$. In terms of sulfur doses, as the mean of years and $\mathrm{P}$ doses, the highest protein ratio was determined at $\mathrm{S}_{30}(26.0 \%)$ dose and the lowest at $\mathrm{S}_{0}(25.3 \%)$ dose. In terms of phosphorus doses, increasing $\mathrm{P}$ doses increased protein content in fenugreek, but statistically, $\mathrm{P}$ doses, except for $\mathrm{P}_{0}$, were in the same group (Table 5). Baldaneeya Nitesh (2018) and Tunçtürk et al. (2011) stated that they determined the highest protein content at a dose of $40 \mathrm{~kg} \mathrm{ha}^{-1} \mathrm{~S}$. Mehta et al. (2012) reported that although increasing $\mathrm{P}$ doses increased protein content, there was no 
difference between 20 and $40 \mathrm{~kg} \mathrm{ha}^{-1} \mathrm{P}$ doses. Tunçtürk (2011) also reported similar results.

Table 5. Means of yield, protein and trigonelline ratio at different sulfur and phosphorus doses in fenugreek

\begin{tabular}{|c|c|c|c|c|c|c|c|c|c|c|}
\hline \multirow{2}{*}{$\begin{array}{c}\mathbf{S} \\
\text { doses }\end{array}$} & \multirow{2}{*}{$\begin{array}{c}\mathbf{P} \\
\text { doses }\end{array}$} & \multicolumn{3}{|c|}{ Seed yield $\left(\mathrm{kg} \mathrm{ha}^{-1}\right)$} & \multicolumn{3}{|c|}{ Protein ratio (\%) } & \multicolumn{3}{|c|}{ Trigonelline ratio (\%) } \\
\hline & & 2017 & 2018 & Mean* & 2017 & 2018 & Mean* & 2017 & 2018 & Mean* \\
\hline \multirow{4}{*}{$\mathrm{S}_{0}$} & $\mathrm{P}_{0}$ & 1005 & 1071 & 10381 & 24.6 & 25.1 & 24.9 & 0.78 & 0.83 & 0.811 \\
\hline & $\mathrm{P}_{30}$ & 1121 & 1241 & $1182 \mathrm{~h}$ & 24.9 & 25.5 & 25.2 & 0.88 & 0.91 & $0.90 \mathrm{~h} 1$ \\
\hline & $\mathrm{P}_{60}$ & 1323 & 1432 & $1378 \mathrm{fg}$ & 25.2 & 25.6 & 25.4 & 0.91 & 0.94 & $0.93 \mathrm{gh}$ \\
\hline & $\mathrm{P}_{90}$ & 1520 & 1527 & $1523 \mathrm{de}$ & 25.5 & 25.8 & 25.6 & 0.93 & 0.95 & $0.94 \mathrm{efg}$ \\
\hline $\mathrm{S}_{0} \mathrm{~N}$ & lean & 1242 & 1318 & $1280 \mathrm{D}$ & 25.1 & 25.5 & $25.3 \mathrm{C}$ & 0.89 & 0.88 & $0.89 \mathrm{D}$ \\
\hline \multirow{4}{*}{$\mathrm{S}_{10}$} & $\mathrm{P}_{0}$ & 1199 & 1246 & $1223 \mathrm{~h}$ & 25.6 & 24.9 & 25.3 & 0.84 & 0.89 & $0.87 \mathrm{~h}$ \\
\hline & $\mathrm{P}_{30}$ & 1270 & 1327 & $1299 \mathrm{gh}$ & 25.8 & 25.2 & 25.5 & 0.87 & 0.89 & $0.88 \mathrm{~h}$ \\
\hline & $\mathrm{P}_{60}$ & 1462 & 1416 & 1439 ef & 25.7 & 25.5 & 25.6 & 0.92 & 0.94 & $0.93 \mathrm{gh}$ \\
\hline & $\mathrm{P}_{90}$ & 1501 & 1559 & $1530 \mathrm{de}$ & 25.8 & 25.7 & 25.8 & 0.94 & 0.96 & $0.95 \mathrm{ef}$ \\
\hline $\mathrm{S}_{10} \mathrm{I}$ & Iean & 1358 & 1387 & $1373 \mathrm{C}$ & 25.7 & 25.4 & $25.5 \mathrm{~B}$ & 0.91 & 0.89 & $0.90 \mathrm{C}$ \\
\hline \multirow{4}{*}{$\mathrm{S}_{20}$} & $\mathrm{P}_{0}$ & 1234 & 1283 & $1259 \mathrm{gh}$ & 25.7 & 25.3 & 25.5 & 0.98 & 0.99 & $0.99 \mathrm{e}$ \\
\hline & $\mathrm{P}_{30}$ & 1329 & 1374 & $1351 \mathrm{fg}$ & 25.9 & 25.6 & 25.8 & 1.09 & 1.12 & $1.11 \mathrm{c}$ \\
\hline & $\mathrm{P}_{60}$ & 1661 & 1584 & $1622 \mathrm{~cd}$ & 26.0 & 25.8 & 25.9 & 1.10 & 1.14 & $1.12 \mathrm{c}$ \\
\hline & $\mathrm{P}_{90}$ & 1902 & 2027 & $1964 \mathrm{~b}$ & 25.7 & 25.6 & 25.9 & 1.19 & 1.22 & $1.21 \mathrm{ab}$ \\
\hline $\mathrm{S}_{20} \mathrm{I}$ & Iean & 1531 & 1567 & $1549 \mathrm{~B}$ & 25.8 & 25.7 & $25.8 \mathrm{~B}$ & 1.09 & 1.12 & $1.11 \mathrm{~B}$ \\
\hline \multirow{4}{*}{$\mathrm{S}_{30}$} & $\mathrm{P}_{0}$ & 1428 & 1430 & 1429 ef & 25.7 & 26.1 & 25.9 & 1.04 & 1.06 & $1.05 \mathrm{~d}$ \\
\hline & $\mathrm{P}_{30}$ & 1692 & 1687 & $1690 \mathrm{c}$ & 26.0 & 26.2 & 26.1 & 1.16 & 1.19 & $1.18 \mathrm{~b}$ \\
\hline & $\mathrm{P}_{60}$ & 1898 & 1989 & 1944 b & 26.0 & 26.4 & 26.2 & 1.20 & 1.23 & $1.22 \mathrm{ab}$ \\
\hline & $\mathrm{P}_{90}$ & 2043 & 2405 & $2224 \mathrm{a}$ & 25.3 & 26.5 & 25.9 & 1.25 & 1.26 & $1.26 \mathrm{a}$ \\
\hline $\mathrm{S}_{30} \mathrm{I}$ & Iean & 1765 & 1879 & $1822 \mathrm{~A}$ & 25.8 & 26.3 & $26.0 \mathrm{~A}$ & 1.17 & 1.19 & $1.18 \mathrm{~A}$ \\
\hline \multicolumn{11}{|c|}{ Phosphorus mean } \\
\hline & & 1217 & 1258 & $1237 \mathrm{~d}$ & 25.4 & 25.4 & $25.4 \mathrm{~b}$ & 0.91 & 0.94 & $0.93 \mathrm{c}$ \\
\hline & & 1353 & 1408 & $1380 \mathrm{c}$ & 25.7 & 25.6 & $25.6 \mathrm{a}$ & 1.00 & 1.03 & $1.02 \mathrm{~b}$ \\
\hline & & 1586 & 1605 & $1596 \mathrm{~b}$ & 25.8 & 25.8 & $25.8 \mathrm{a}$ & 1.03 & 1.06 & $1.05 \mathrm{~b}$ \\
\hline & & 1741 & 1879 & $1810 \mathrm{a}$ & 25.6 & 26.0 & $25.8 \mathrm{a}$ & 1.08 & 1.10 & $1.09 \mathrm{a}$ \\
\hline $\mathrm{Me}$ & ans & 1474 & 1538 & & 25.6 & 25.7 & & 1.02 & 1.04 & \\
\hline $\mathrm{CV}$ & $(\%)$ & & 7.0 & & & 1.6 & & & 4.1 & \\
\hline Yea & $(\mathrm{Y})$ & & $* *$ & & & ns & & & ns & \\
\hline Sulf & $r(S)$ & & $* *$ & & & $* *$ & & & $* *$ & \\
\hline Phosph & rus $(\mathrm{P})$ & & $* *$ & & & $* *$ & & & $* *$ & \\
\hline & & & $* *$ & & & ns & & & $* *$ & \\
\hline SxI & $x Y$ & & ns & & & $\mathrm{ns}$ & & & $\mathrm{ns}$ & \\
\hline
\end{tabular}

$\mathrm{S}_{0}=$ Control, $\mathrm{S}_{10}=10 \mathrm{~kg} \mathrm{ha}^{-1}$ sulfur, $\mathrm{S}_{20}=20 \mathrm{~kg} \mathrm{ha}^{-1}$ sulfur, $\mathrm{S}_{3}=30 \mathrm{~kg} \mathrm{ha}^{-1}$ sulfur, $\mathrm{P}_{0}=$ Control, $\mathrm{P}_{30}=30 \mathrm{~kg}$ ha $^{-1}$ phosphorus, $\mathrm{P}_{60}=60 \mathrm{~kg} \mathrm{ha}^{-1}$ phosphorus, $\mathrm{P}_{90}=90 \mathrm{~kg} \mathrm{ha}^{-1}$ phosphorus, $*$ : The difference between the means indicated by the same letter in the same column and group is not significant, $\mathrm{CV}$ : Coefficient of variation, ns: Not significant, $* *: \mathrm{p}<0.01$

\section{Trigonelline content}

The effects of $\mathrm{S}$ and $\mathrm{P}$ doses and SxP interaction on the trigonelline content of fenugreek seeds were found to be significant at the $\mathrm{p}<0.01$ level (Table 5). When Table 5 was examined, the highest trigonelline content was determined in $\mathrm{S}_{30} \mathrm{P}_{90}$ $(1.26 \%)$, but there was no statistically significant difference between $\mathrm{S}_{30} \mathrm{P}_{60}(1.22 \%)$ and $\mathrm{S}_{20} \mathrm{P}_{90}(1.21 \%)$. On the other hand, as both $\mathrm{S}$ and $\mathrm{P}$ doses increased, trigonelline content was observed to increase (Table 5). Kan et al. (2007) stated that applied different phosphorous fertilizer sources did not change the trigonelline content, that trigonelline 
content varied between 0.86-1.26\%, and that ecological factors might be effective on the trigonelline content. Dar et al. (2015) reported that a $40 \mathrm{~kg} \mathrm{P} \mathrm{ha}{ }^{-1}$ application increased the trigonelline content. Mutlu (2011) reported in the study conducted in fenugreek of different origins that the trigonelline content varied between $0.66-1.40 \%$. The trigonelline content obtained in this study was higher than the values reported by Akgül (1993) (0.36\%), Mehrafarin et al. (2010) (0.20-0.36\%), and Mathur and Yadav (2011) $(0.27 \%)$.

\section{Relationships between the investigated properties}

The simple correlation coefficients showing linear relationships between the seed yield per plant and the investigated properties were presented in Table 6. The correlation analysis revealed that the seed yield was positively and significantly correlated with the number of pods per plant $\left(\mathrm{r}=0.703^{* * *}\right)$, pod length $\left(\mathrm{r}=0.334^{* * *}\right)$, the number of seeds per pod $\left(\mathrm{r}=0.509^{* * *}\right)$, and thousand-seed weight $\left(\mathrm{r}=0.571^{* *}\right)$. Increases that occurred in these properties caused significant increases in the plant seed yield. The highest correlation coefficients in terms of seed yield were determined in the relationships between the number of pods per plant, the number of seeds per pod, and thousand-seed weight. Parchin et al. (2019) stated that there was a positive relationship between the number of pods per plant and seed yield.

Table 6. Correlation coefficients related to pairwise relations between the seed yield and other properties

\begin{tabular}{l|cccccc}
\hline & $\mathbf{2}$ & $\mathbf{3}$ & $\mathbf{4}$ & $\mathbf{5}$ & $\mathbf{6}$ & $\mathbf{7}$ \\
\hline 1. Plant height & $0.274^{* *}$ & 0.094 & $0.218^{*}$ & $0.243^{*}$ & 0.104 & 0.154 \\
2. First pod height & - & $0.280^{* *}$ & 0.080 & 0.068 & 0.110 & 0.078 \\
3. Number of pods per plant ${ }^{-1}$ & & - & $0.391^{* *}$ & $0.478^{* *}$ & $0.436^{* *}$ & $0.703^{* *}$ \\
4. Pod length & & & - & $0.343^{* *}$ & $0.321^{* *}$ & $0.334^{* *}$ \\
5. Number of seeds per pod ${ }^{-1}$ & & & & - & $0.299^{* *}$ & $0.509^{* *}$ \\
6. Thousand-seed weight & & & & & - & $0.571^{* *}$ \\
7. Seed yield & & & & & - \\
\hline
\end{tabular}

*: Significant at the $\mathrm{p}<0.05$ level, **: Significant at the $\mathrm{p}<0.01$ level

A positive and significant relationship was determined between plant height and the first pod height. Positive and significant relationships were detected between the number of pods per plant and pod length and between the number of seeds per pod and thousand-seed weight. Positive and significant relationships were found between the thousand-seed weight and the number of pods per plant and between pod length and the number of seeds per pod. The number of pods per plant was stated to be the most important factor affecting seed yield in many studies (Şehirali, 1980; Pooran-Chand, 1999; Amini et al., 2002; Kumar Singh et al., 2019, Singh et al., 2019), and finding the number of pods per plant as the most leading factor in this study supports the other literature on this subject.

\section{Conclusions}

This study, which was carried out under the ecological conditions of Siirt province located in the Southeastern Anatolia Region of Turkey, which has a semi-arid climate, revealed the importance of sulfur and phosphorus fertilizers when an evaluation was 
made in terms of yield and some quality criteria. Increased sulfur and phosphorus doses positively affected all of the investigated properties. When an evaluation was made in terms of yield and yield components, $30 \mathrm{~kg} \mathrm{~S}$ and $90 \mathrm{~kg} \mathrm{P}$ doses could be stated to be suitable for per hectare. However, it was revealed that studies involving further increasing doses of both elements should be performed due to the linear increase determined in yield and quality properties in parallel to the increasing sulfur and phosphorus doses.

\section{REFERENCES}

[1] Abdelgani, M. E., Elsheikh, E. A. E., Mukhtar, N. O. (1999): The effect of Rhizobium inoculation and chemical fertilization on seed quality of fenugreek. - Food Chemistry 64: 289-293.

[2] Abd Elhamid, E. M., Sadak, M. S., Tawfik, M. M. (2016): Physiological response of fenugreek plant to the application of proline under different water regimes. - Research Journal of Pharmaceutical, Biological and Chemical Sciences 7(3): 580-594.

[3] Ahmad, T. S. (2017): Study the effect of phosphorus fertilizer and seaweeds extracts on the growth, yield, and oil percentage of fenugreek Trigonelle foenum-graecum L. - Tikrit Journal for Agricultural Sciences 17(2): 87-93.

[4] Akgül, A. (1993): Spices science and technology. - Food Technology Association Publications, No.15. Ankara, Turkey. (In Turkish).

[5] Amini, A., Ghannadha, M., Abd-Mishani, C. (2002): Genetic diversity and correlation between different traits in common bean (Phaseolus vulgaris L.). - Iranian J. of Agricultural Sci. 33(4): 605-615.

[6] Anonymous (2018): Data from the General Directorate of Meteorology.

[7] Arslan, N., Tekeli, S., Gençtan, T. (1989): Seed yields of fenugreek (Trigonella foenumgraecum L.) populations from different regions. - VIII. Proceedings Book of Herbal Medicine Raw Materials Meeting Proceedings 2: 93-97.

[8] Babagil, G. E. (2010): A study on yield and yield components of some chickpea (Cicer arietinum L.) varieties in Muş egological conditions. - Journal of Tekirdag Agricultural Faculty 7(3): 181-186.

[9] Baldaneeya Nitesh, S. (2018): Responce of fenugreek (Trigonella foenum-graecum L.) to phosphorus and sulphur. - Junagadh Agricultural University, MSc. Thesis.

[10] Baldemir, A., İlgün, S. (2015): Usage areas of fenugreek in the past and today: Trigonella foenum-graecum L. - Lokman Hekim Journal 5(1): 1-4.

[11] Basu, S. K., Cetzal-Ix, W., Zandi, P., Możdżeń, K., Siavoshi, M. (2019): Rich potential for fenugreek (Trigonella foenum-graecum L.) cultivation in Iran. - The $2^{\text {nd }}$ International Conference on Medicinal Plants, Organic Farming, Natural and Medicinal Materials, 13-14 February.

[12] Baytop, T. (1984): Treatment with Plants. - İstanbul University, Faculty of Pharmacy Publications. No: 3255. (In Turkish).

[13] Bhunia, S. R., Chauhan, R. P. S., Yadav, B. S., Bhati, A. S. (2006): Effect of phosphorus, irrigation and Rhizobium on productivity, water use and nutrient uptake in fenugreek (Trigonella foenum-graecum L). - Indian Journal of Agronomy 51(3): 239-241.

[14] Boeker, P. (1963): Forage Crops. - Ege University, Faculty of Agriculture. No: 82. Translation: Demir, I. pp. 97-98.

[15] Bolat, İ., Kara, Ö. (2007): Plant nutrients: sources, functions, deficiencies and redundancy. - Journal of Bartin Faculty of Forestry 19(1): 218-228. (In Turkish).

[16] Dar, T. A., Uddin, M., Masroor Khan, M. A., Akbar A., Rasool Mir, S., Varshney, L. (2015): Effect of Co-60 gamma irradiated chitosan and phosphorus fertilizer on growth, 
yield and trigonelline content of Trigonella foenum-graecum L. - Journal of Radiation Research and Applied Sciences 8: 446-458.

[17] Davis, P. H. (1982): Flora of Turkey and The East Aegean Islands. - Edinburgh Univ. Press 3: 465-482.

[18] Düzgüneş, O., Kesici, T., Kavuncu, O., Gürbüz, F. (1987): Research and Experimental Methods. - Ank. Univ. Agr. Fac. Pub. Lecture book. No. 295. (In Turkish).

[19] Gezgin, S. (2018): Plant nutrition and fertilization in edible legumes. - Edible Legumes Workshop, 10-12 Mayıs 2017, Adana/Turkey, pp. 181-195. (In Turkish).

[20] Gökmen Yılmaz, F., Harmankaya, M., Gezgin, S., Dursun, N., Hamurcu, M., Hakkı, E. E. (2017): Phosphorus efficiency of mainly grown beans in Turkey. - IPNC Congress, 21-24.08.2017, Kopenhag/Danimarka.

[21] Halesh, D. P., Gowda, M. C., Forooqi, A. A., Vasundhara, M., Srinivasappa, K. N. (2000): Influence of nitrogen and phosphorus on growth, yield and nutrient content of fenugreek (Trigonella foenum - graecum L.). Spices and aromatic plants: challenges and opportunities in the new century. - Contributory papers. Centennial conference on spices and aromatic plants, Calicut, Kerala, India, 20-23 September, pp. 191-194.

[22] Hornok, L. (1992): The cultivation of medicinal plants. - In: Hornok, L. (ed.) Cultivation and processing of medicinal plants. Budapest, pp. 289-290.

[23] Kacar, B., Katkat, A. V. (2007): Plant nutrition. - Nobel Publication Distribution. (In Turkish).

[24] Kan, Y., Kartal, M., Abuataker, M. (2007): The effect of organic and inorganic fertilizer on some quality characters of fenugreek seeds (Trigonella foenum graecum L.). - Selcuk University Journal of Agriculture 21(41): 118-122.

[25] Khiriya, K. D., Sheoran, R. S., Singh, B. S. (2001): Growth analysis of fenugreek (Trigonella foenum- graecum L.) under various levels of farmyard manure and phosphorus. - Journal of Spices and Aromatic Crops 10(2): 105-110.

[26] Khiriya, K. D., Singh, B. S. (2003): Effect of phosphorus and farmyard manure on yield, yield attributes and nitrogen, phosphorus and potassium uptake of fenugreek (Trigonella foenum-graecum L.). - Indian Journal of Agronomy 48(1): 62-65.

[27] Kizıl, S., Arslan, N. (2003): Investigation of the effects on yield and yield components of different sowing rates in some fenugreek (Trigonella foenum-graecum L.) lines. - Journal of Agriculture Science 9(4): 395-401.

[28] Küçük, M., Gürbüz, B. (1999): A research on oil content and fatty acid composition of some fenugreek (Trigonella foenum graecum L.) lines. - Journal of Food 24(2): 99-101.

[29] Kumar, J. (2011): Effect of phosphorus and sulphur application on performance of vegetable pea (Pisum sativum L.) cv. pant matar-2. - Legume Research-An International Journal 34(4): 292-295.

[30] Kumar Singh, A., Singh, D. R., Singh, A., Kumar Maurya, J., Pandey, V. P., Sriom. (2019): Studies on character association and path analysis of yield with important yield contributing traits in fenugreek (Trigonella foenum-graecum L.). - Journal of Pharmacognosy and Phytochemistry 8(3): 4616-4619.

[31] Lal, G., Singh, B., Mehta, R. S., Singh, R., Maheria, S. P. (2015): Performance of fenugreek (Trigonella foenum-graecum L.) as influenced by sulphur and zinc. International Journal of Seed Spices 5(1): 29-33.

[32] Manesh, A. K., Armin, M., Moeini, M. J. (2013): The effect of sulfur application on yield and yield components of corn in two different planting methods in saline conditions. International Journal of Agronomy and Plant Production 4(7): 1474-1478.

[33] Mathur, L., Yadav, R. K. (2011): Effect of salicylic acid on trigonelline production in Trigonella foenum- graecum L. cell suspension culture. - International Referred Reseach Journal 1(17): 137-138.

[34] Meena, R. K., Meena, R. N., Yadav, L., Sharma, O. P. (2012): Effect of phosphorus, molybdenum, PSB levels on growth, productivity and nutrient uptake of fenugreek (Trigonella foenum-graecum L.). - Environment \& Ecology 30(3B): 825-829. 
[35] Mehrafarin, A., Qaderi, A., Rezazadeh, Sh., Naghdi Badi, H., Noormohammadi, Gh., Zand, E. (2010): Bioengineering of important secondary metabolites and metabolic pathways in fenugreek (Trigonella foenum-graecum L.). - Journal of Medicinal Plants 9(35): $1-18$.

[36] Mehta, R. S., Anwer, M. M., Aishwath, O. P., Meena, R. S. (2012): Growth, yield and quality of fenugreek (Trigonella foenum-graecum L.) as influenced by nitrogen, phosphorus and bio-fertilizers. - Indian Journal of Horticulturae 69(1): 94-97.

[37] Mitoo, S. M. M. R., Sujan, M. H. K. (2018): Faijul, I. Effect of phosphorous and sulphur fertilization on seed yield of fenugreek (Trigonella foenum-graecum L.). - IOSR Journal of Agriculture and Veterinary Science 11(1): 5-17.

[38] Mohamed El-Sayed Ali, M. (2018): Efficiency of elemental sulfur and phosphorus fertilizer in enhancing soybean (Glycine $\max$ L.) growth and yield in a clayey soil. Egyptian Journal of Soil Science 58(2): 233-244.

[39] Mutlu, S. (2011): Determination of some phenological, morphological, yield and quality characteristics of fenugreeks (Trigonella foenum-graceum L.) from different origins. Master Thesis. OMÜ, Graduate School of Natural and Applied Sciences. 103p. (In Turkish).

[40] Nawange, D. D., Yadav, A. S., Singh, R. V. (2011): Effect of phosphorus and sulphur application on growth, yield attributes and yield of chickpea (Cicer arietinum L). Legume Research 34(1): 48-50.

[41] Nehara, K. C., Kumawat, P. D., Singh, B. P. (2006): Response of fenugreek (Trigonella foenum-graecum) to phosphorus, sulphur and plant-growth regulators under semi-arid eastern plains zone of Rajasthan. - Indian Journal of Agronomy 51(1): 73-76.

[42] Parchin, R. A., Ghomi, A. A. N., Hasanali, N. B., Eskandari, A., Navabpour, S., Mehrafarin, A. (2019): Growth characteristics and phytochemical responses of Iranian fenugreek (Trigonella foenum-graecum L.) exposed to gamma irradiation. - Industrial Crops \& Products 139: 111593.

[43] Pooran-Chand, P. (1999): Character association and path analysis in rajmash. - Madras Agricultural J. 85: 188-190.

[44] Ramkishor, V. H. P., Kumawat, B. L. (2015): Effect of clay mixing, irrigation and sulphur on growth and yield of fenugreek on loamy sand soil. - Asian Journal of Soil Science 10(1): 29-33.

[45] Sammuria, R., Yadav, R. S. (2008): Effect of phosphorus and zinc application on growth and yield of fenugreek (Trigonella foenum-graecum) and their residual effect on succeeding pearl millet (Pennisetum glaucum) under irrigated conditions of north west Rajasthan. - Indian Journal of Agricultural Sciences 78(1): 61-64.

[46] Singh, N., Singh, G. (2016): Response of lentil (Lens culinaris Medikus) to phosphorusA review. - Agricultural Reviews 37(1): 27-34.

[47] Singh, A., Pandey, V. P., Kumar, P., Kumar, M., Kumar, S., Vaishya, D. V. (2019): To study of correlation coefficient and path coefficient analysis for different characters in germplasm of fenugreek (Trigonella foenum graecum L.). - Journal of Pharmacognosy and Phytochemistry 8(1): 857-861.

[48] Singh Manohar, M., Shivran, A. C., Choudhary, A. (2017): Effect of sulphur and molybdenum on yield attributes, yield and economics of fenugreek. - Chemical Science Review and Letters 7(21): 94-97.

[49] Soylu, S., Sade, B., Atalay, E., Pilgir, Ç., Çetinkaya, Ü. (2000): Effects of different sowing times on yield and yield components of fenugreek (Trigonella foenum graecum L.) genotypes. - Selcuk University Journal of Agriculture 14(22): 131-142. (In Turkish).

[50] Srivastava, M., Niraj Kumar, J. H. A., Singh, B. H. (2015): Effect of nitrogen and phosphourus on growth, leaf and seed yield of fenugreek (Trigonella foenum-graecum $\mathrm{L}$.) cv. 'Pusa early bunching'. - Annals of Agri-Bio-Research 20(1): 51-53. 
[51] Şehirali, S. (1980): The effect of sowing frequency on some yield related traits in dwarf bean (Ph. vulgaris L. var. nanus Dekap). - A. Ü. Agr. Fac. Pub: 738. Scientific Research and Studies: 29, Ankara, Turkey.

[52] Tonguç, M., Şanl1, A., Karakurt, Y., Ünlü, H. (2017): Determining the effects of sulphur applications on yield and yield components of bean. - Alatarım 16(1): 44-51. (In Turkish).

[53] Tunçtürk, R. (2011): The effects of varying row spacing and phosphorus doses on the yield and quality of fenugreek (Trigonella foenum-graecum L.). - Turkish Journal of Field Crops 16(2): 142-148.

[54] Tunçtürk, R., Çelen, A. E., Tunçtürk, M. (2011): The effects of nitrogen and sulphur fertilizers on the yield and quality of fenugreek (Trigonella foenum-graecum L.). Turkish Journal of Field Crops 16(1): 69-75.

[55] Turan, M., Horuz, A. (2012): Plant nutrition. - In: Rüştü Karaman, M. (ed.) Basic principles of plant nutrition. pp. 123-347. (In Turkish).

[56] Verma, S. R., Shivran, A. C., Bhanwaria, R., Singh, M. (2017): Effect of vermicompost and sulphur on growth, yield and nutrient uptake of fenugreek (Trigonella foenumgraecum L.). - Trends in Biosciences 10(20): 3978-3981.

[57] Yadav, S. K., Patel, A. G., Yadav, B. L. (2014): Yield, quality and soil fertility of cluster bean (Cyamopsis tetragonoloba L.) as influenced by various row spacing and levels of phosphorus. - Advance Research Journal Of Crop Improvement 5(2): 101-104.

[58] Yurtsever, N. (1984): Experimental Statistical Methods. Ministry of Agriculture, Forestry and Rural Affairs. - General Directorate of Rural Services Publication No: 623. (In Turkish).

[59] Zhao, Y., Xiao, X., Bi, D., Hu, F. (2008): Effects of sulfur fertilization on soybean root and leaf traits and soil microbial activity. - Journal of Plant Nutrition 31: 473-483. 